\title{
New mite species associated with certain plant species from Guam
}

\begin{abstract}
Several new mite species have been reported from certain plants from Guam. Most remarkably, the spider mite, Tetranychus marianae (Prostigmata: Tetranychidae) and the predatory mite Phytoseius horridus (Mesostigmata: Phytoseiidae) (Solanum melongena) have been found on eggplant. The noneconomically important species of Brevipalpus californicus(Banks) Prostigmata: Tenuipalpidae),Eupodes sp. (Acarina: Eupodidae) and predator Cunaxa sp. (Prostigmata: Cunaxidae) have been reported on guava (Psidium guajava L.). Also, the non-economically important species Brevipalpus californicusProstigmata: Tenuipalpidae), Lepidoglyphus destructor (Astigmata: Glycyphagidae) and a predator Amblyseius obtusus, species groupAmblyseius near lentiginosus (Mesostigmata: Phytoseiidae), have been recorded on cycad (Cycas micronesica).
\end{abstract}

Key words - Tetranychus marianae, new mite species, eggplant, cycad, guava, pepper, Guam

\section{INTRODUCTION}

Spider mites are common pest problems on many plants around yards and gardens in Guam and other parts of the USA. Guam has been a transportation hub for several major airlines and shipping companies, with extensive connections to other Pacific islands in Micronesia, Asia, and the continental USA. There are numerous direct flights from Guam to Cairns (Australia), Seoul (South Korea), Manila (Philippines), Osaka/Tokyo (Japan), Taipei (Taiwan), Hawaii, and to other Micronesian islands, that raise concern about the possibility of introducing mite species to Guam from other areas of current infestation. The introduction of mite species reported in the above Asian countries to Guam would increase the probability of their introduction into other areas of the USA. Perhaps of most concern is the presence of various spider mites and broad mites in Japan, Taiwan and Korea, which greatly increases the probability of their introduction to Guam, the Commonwealth of the Northern Mariana Islands, and other islands of Micronesia given the high flow of civilian, military and cargo traffic between these areas by direct air and sea routes. Additionally, some of Guam's food supply is directly imported from Asian countries including, but not limited to the Philippines, Korea and Japan. While no such 
work on mites in Guam has been done thus far, there is a possibility that mites may have come in with such food shipments. Local farmers and producers have already brought to our knowledge information about the occurrence of mites on vegetables and other such crops. Because there have been no studies conducted on mites locally, we have no knowledge as to what mites may be present in this region. Consequently, surveillance of phytophagous mites will allow local authorities in Guam, the CNMI, and elsewhere in non-infested areas of the Pacific to take immediate action upon their discovery, thereby lessening the chance of successful establishment and spread of the mites throughout the region. Therefore, surveillance work was initiated on Guam to record the incidence of mites on various crop plants.

\section{MATERIAL AND METHODS}

The mites provided in vials were prepared by the following method. Leaves were collected from the various agricultural plants, and taken back to the laboratory where they were examined under a microscope. All mites occurring on a leaf were collected with a small paint brush moistened with $70 \%$ ethanol, placed in a vial containing $5 \mathrm{ml}$ of $70 \%$ ethanol, labeled, and prepared for shipping. The vials with mites were sent to Angela Marmont Centre for UK Biodiversity, Natural History Museum, London for identification.

\section{RESULTS}

Several new mite species, both of economically, and non-economically important plants have been identified, and the presence of a predatory mite species confirmed. These are shown in Table 1.

\section{Eggplant, (Solanum melongena)}

Specimen-1: The spider mite, Tetranychus marianaeMcGregor, 1950 (Prostigmata: Tetranychidae) was the dominant mite species recorded from the samples collected from eggplant. The form of the aedeagus is an important character for confirming species identity. However, the females conform to the redescription of T. marianae given in Moraes et al. (1987).

Distribution: Widespread in the Pacific islands, e.g., the Marianas, from where it was first described. It has previously been recorded from eggplant on Guam (De Moraes et al., 1987) but disappeared until recently. Other distribution records include Australia, Bahamas, Central, South and North (Mexico, Florida) America, West Indies and Southeast Asia. 
Table 1 - Mite species recorded on different host plants on Guam

\begin{tabular}{|c|c|c|c|}
\hline Scientific name & $\begin{array}{l}\text { Associated with Host } \\
\text { plants / prey species }\end{array}$ & $\begin{array}{l}\text { Pest or } \\
\text { Predatory }\end{array}$ & $\begin{array}{l}\text { Location with } \\
\text { GPS points }\end{array}$ \\
\hline $\begin{array}{l}\text { Tetranychus marianae } \\
\text { McGregor, } 1950 \\
\text { (Prostigmata: } \\
\text { Tetranychidae) }\end{array}$ & $\begin{array}{l}\text { Eggplant (Solanum } \\
\text { melongena L.) }\end{array}$ & Pest & $\begin{array}{l}\text { Mangilao } \\
\left(13.43^{\circ} \mathrm{N}\right. \\
\left.144.80^{\circ} \mathrm{E}\right)\end{array}$ \\
\hline $\begin{array}{l}\text { Phytoseius horridusRibaga, } \\
1904 \text { (Mesostigmata: } \\
\text { Phytoseiidae) }\end{array}$ & $\begin{array}{l}\text { Eggplant (Solanum } \\
\text { melongena L.) }\end{array}$ & Predatory & $\begin{array}{l}\text { Mangilao } \\
\left(13.43^{\circ} \mathrm{N},\right. \\
\left.144.80^{\circ} \mathrm{E}\right)\end{array}$ \\
\hline $\begin{array}{l}\text { Brevipalpus } \\
\text { californicus(Banks) } \\
\text { Prostigmata: Tenuipalpidae) }\end{array}$ & Guava (Psidiumguajava L.) & $\begin{array}{l}\text { Feed on higher } \\
\text { plants }\end{array}$ & $\begin{array}{l}\text { Yigo }\left(13.54^{\circ} \mathrm{N},\right. \\
\left.144.89^{\circ} \mathrm{E}\right)\end{array}$ \\
\hline $\begin{array}{l}\text { Cunaxa sp. (Prostigmata: } \\
\text { Cunaxidae) }\end{array}$ & Guava (Psidium guajava L.) & Predatory & $\begin{array}{l}\text { Yigo }\left(13.54^{\circ} \mathrm{N},\right. \\
\left.144.89^{\circ} \mathrm{E}\right)\end{array}$ \\
\hline $\begin{array}{l}\text { Eupodes sp. (Acarina: } \\
\text { Eupodidae) }\end{array}$ & Guava (Psidium guajava L.) & $\begin{array}{l}\text { Many live in } \\
\text { soil and leaf } \\
\text { litter (not } \\
\text { regarded as } \\
\text { pests) }\end{array}$ & $\begin{array}{l}\text { Yigo }\left(13.54^{\circ} \mathrm{N},\right. \\
\left.144.89^{\circ} \mathrm{E}\right)\end{array}$ \\
\hline $\begin{array}{l}\text { Brevipalpus } \\
\text { californicus(Banks) } \\
\text { Prostigmata: Tenuipalpidae) }\end{array}$ & $\begin{array}{l}\text { Cycad (Cycas micronesica } \\
\text { K.D. Hill) }\end{array}$ & $\begin{array}{l}\text { feed on higher } \\
\text { plants }\end{array}$ & $\begin{array}{l}\text { Dededo } \\
\left(13^{\circ} 30.700^{\prime} \mathrm{N},\right. \\
\left.144^{\circ} 51.173^{\prime} \mathrm{E}\right)\end{array}$ \\
\hline $\begin{array}{l}\text { Lepidoglyphus destructor } \\
\text { (Schrank) (Astigmata: } \\
\text { Glycyphagidae) }\end{array}$ & $\begin{array}{l}\text { Cycad (Cycas micronesica } \\
\text { K.D. Hill) }\end{array}$ & $\begin{array}{l}\text { Mites of } \\
\text { this genus } \\
\text { are common } \\
\text { inhabitants of } \\
\text { house dust and } \\
\text { stored food }\end{array}$ & $\begin{array}{l}\text { Merizo } \\
\left(13^{\circ} 15.058^{\prime} \mathrm{N},\right. \\
\left.144^{\circ} 43.071^{\prime} \mathrm{E}\right)\end{array}$ \\
\hline $\begin{array}{l}\text { Amblyseius obtusus species } \\
\text { group, Amblyseius near } \\
\text { lentiginosusDenmark } \\
\text { \&Schicha (Mesostigmata: } \\
\text { Phytoseiidae) }\end{array}$ & $\begin{array}{l}\text { Cycad (Cycas micronesica } \\
\text { K.D. Hill) }\end{array}$ & predatory & $\begin{array}{l}\text { Tamuning } \\
\left(13^{\circ} 30.109^{\prime} \mathrm{N},\right. \\
\left.144^{\circ} 46.939^{\prime} \mathrm{E}\right)\end{array}$ \\
\hline
\end{tabular}

Significance: Tetranychus marianae is known as a pest of tomato and cotton, but also occurs on a wide range of other plants, e.g., castor bean (Ricinus communis), passion flower (Passiflora edulis), squash (Cucurbita maxima), Centrosema pubescens, sweet potato (Ipomoea batatas), Merremia vitifolia and Orchidaceae. Spider mites feed on leaf cell contents and feeding activity is indicated by the appearance of pale areas on the upper leaf surface as chlorophyll is removed. 
Biology: The egg to adult life span lasted $10.73 \pm 0.18$ days, with a $92 \%$ survival. The sex ratio was $81 \%$ females. The mean female longevity was 24.53 days and the daily mean oviposition was 3.69 eggs / female. The intrinsic rate of increase (rm) was 0.172; the finite rate of increase $(\mathrm{X})$ was 1.187 individuals / female / day; the mean time span of one generation (T) was 22.81 days; and the net rate of reproduction (R0) was 50.14 (Noronha, 2006).

Specimen-2: Phytoseius horridus species group (Mesostigmata: Phytoseiidae):

Phytoseius horridus, most probably P. mayottae Schicha, were identified from adult females.

Phytoseiids are predominantly predators of other small arthropods, including pest species. Phytoseius mayottae was originally described from specimens collected in Mayotte Island (near Madagascar), but has also been recorded in Sri Lanka, the Seychelles, Vanuatu, New Caledonia and Australia. Host plants include Acalypha sp., Curculigo sp., Flemingia strobilifera, Glycine javanica, Macroptilium atropurpureum, Psidium guajava, Turnera sp. and Solanum melongena (De Moraes et al., 2004). No information is available on its biology and feeding preferences.

\section{Guava (Psidium guajava)}

Spicemen-1: False spider mites, flat mites, Brevipalpus californicus (Banks) (Prostigmata: Tenuipalpidae):

Description: Tenuipalpids have been collected in most parts of the world. They feed on higher plants, usually on the under surface of the leaves. They have long, needlelike cheliceral digits with which they pierce the epidermis and feed on the contents of the underlying cells. Some species are of economic importance. Brevipalpus spp. have been identified as pests of watermelons in Guam (Yudin, 1999). The submitted specimen is morphologically close to B. californicus, a cosmopolitan species that is a pest of a wide range of ornamental and agricultural crops, but differs slightly in the form of the ventral ornamentation.

Spicemen-2: Cunaxa sp. (Prostigmata: Cunaxidae):

Distribution: Fast moving mites, found in a wide variety of habitats, e.g., on plants (including crop species), shrubs and trees, and in moss, bark, soil and food stores. They prey on small arthropods, other mites and nematodes, including pest species (Smiley, 1992).

Spicemen-3: Eupodes sp. (Order Prostigmata)

Species of Eupodes have a worldwide distribution. Many live in soil and leaf litter, but some have been collected on grasses and other plants. Available evidence indicates that their diet is comprised of algae and fungi, and they are not regarded as pests. 
Spicemen-3: Bdellidae, larva (Prostigmata: Bdellidae)

Bdellids have a worldwide distribution. Their diet, habits and habitats are like those of the family Cunaxidae (Smiley, 1992). Some species have been investigated as control agents of pest mites, insects and nematodes (Gerson et al., 2007).

Spicemen-4: Ascinae adult female (Mesostigmata: Ascidae, subfamily Ascinae)

Members of the predatory Ascinae are very diverse in biology and habitat, occurring, for example, on plants and at the sea shore, in salt marshes, soil, humus, stored foods, and bird, mammal and arthropod nests. Species that live on plants prey on other invertebrates or feed on fungi or pollen (Halliday et al., 1998).

\section{Cycad (Cycas micronesica K.D. Hill)}

Spicemen-1:Lepidoglyphus destructor (Schrank) (Astigmata: Glycyphagidae):

Glycyphagids and Lepidoglyphus have a worldwide distribution. Mites of this genus are common inhabitants of house dust and stored foods, e.g., oats, rye, linseed, rice and dried fruit. They also occur in outdoor habitats, e.g., grassland soil, and stacks of grain, straw and hay. They thrive in damp, humid conditions and feed on the microscopic fungi that grow in such environments (Knülle, 1987).

Spicemen-2: Amblyseius obtusus species group, Amblyseius near lentiginosus Denmark \&Schicha, adult female (Mesostigmata: Phytoseiidae)

Description: Members of this species group were originally collected from apple trees and have subsequently been recorded on other plants, e.g., grapevines, Citrus sp., Ficus sp., strawberry, mango, Pinus radiata and Quercus sp. They are known to prey on pest mites, e.g., Panonychus citri (Tetranychidae), and Tegolophus australis and Phyllocoptruta oleivora (both Eriophyidae), and have been evaluated as a biocontrol agent (James et al., 2001)

\section{ACKNOWLEDGMENTS}

This project was supported by FY 2010 United States Department of Agriculture (USDA), Animal and Plant Health Inspection Service (APHIS), Cooperative Agricultural Pest Survey (CAPS) Program Agreement\#10-8510-1302-CA and FY 2009 U.S. Environmental Protection AgencyStrategic Agriculture Initiative / Food Quality Protection Act (FQPA) Grant Agreement \#X8-00T32301-0. The authors thank YolisaIshibashi, Pest Survey Specialist, USDA, APHIS, PPQ, Honolulu, HI 96850 and Cindy Wire, Agriculture Program, US EPA, Region 9, San Francisco, CA 94105 for their encouragement and support during all phases of the project. We also thank Anne Baker, Angela Marmont Centre for UK Biodiversity, Natural History Museum, London for 
identifying the species. In accordance with federal law and USDA policy, this institution is prohibited from discrimination on the basis of race, color, national origin, sex, age, or disability.

\section{REFERENCES}

De Moraes G.J., McMurtry, J.A. \& BaKer, E.A., 1987 - Redescription and distribution of the spider mites Tetranychus evansi and T. marianae. Acarologia, 28: 333-343.

DE Moraes G.J., Lopes P.C., Fernando, L.C.P., 2004 - Phytoseiid mites (Acari: Phytoseiidae) of coconut growing areas in Sri Lanka, with descriptions of three new species. Journal of Acarological Society of Japan, 13: 141-160.

Gerson U., Smiley R. L., OchOA R., 2003 - Mites (Acari) for pest control. Blackwell Publishing, Oxford, UK.

HALLIDAY R.B., WALTER D. E., LiNDQUist E.E., 1998 - Revision of the Australian Ascidae (Acarina: Mesostigmata). Invertebrate Taxonomy, 12: 1-54.

James D.G., Halliday R.B., Walter D.E., Proctor H.C., Norton, R.A., Colloff M.J., 2001 - History and perspectives of biological mite control in Australian horticulture using exotic and native phytoseiids. CSIRO Publishing, Collingwood, Australia, Acarology: Proceedings of the 10th International Congress: 436-443.

KNÜLLE W., 1987 - Genetic Variability and ecological adaptability of hypopus formation in a stored product mite. Experimental and Applied Acarology, 3: 21-32.

NoronHA A.C.S., 2006 - Biological aspects of Tetranychus marianae McGregor (Acari, Tetranychidae) reared on yellow passion fruit (Passiflora edulis Sims f.flavicarpa Deg.) leaves. RevistaBrasileira de Zoologia 23: 404-407.

SMiley R.L., 1992 - The predatory mite family Cunaxidae (Acari) of the world with a new classification. West Bloomfield, Michigan, USA, Indira Publishing House 356 pp.

YUDIN L.S., 1999 - Crop Profile for Water melons in Guam. www.ipmcenters.org/cropprofiles/ docs/GUwatermelons.pdf.

Gadi V.P. Reddy, Rosalie Kikuchi, Jenelyn E. Remolona, Western Pacific Tropical Research Center, University of Guam, Mangilao, Guam 96923, USA, E-mail: reddy@uguam.uog.edu

Accepted 21 April 2011 